\title{
Serum Bone $\gamma$-Carboxyglutamic Acid Protein in a Longitudinal Study of Infants: Lower Values in Formula-Fed Infants
}

\author{
KIM FLEISCHER MICHAELSEN, JULIA SIDENIUS JOHANSEN, GÖSTA SAMUELSON, \\ PAUL A. PRICE, AND CLAUS CHRISTIANSEN
}

\begin{abstract}
Research Department of Human Nutrition. The Royal Veterinary and Agricultural University, Frederiksberg, Denmark [K.F.M.], Department of Clinical Chemistry, University of Copenhagen, Glostrup Hospital, Denmark [J.S.J., C.C.], Department of Paediatrics, Northern Älvsborg Hospital, Trollhättan, Sweden /G.S.], Department of Biology, University of California, San Diego, La Jolla, California 92093 [P.A.P.], Department of Paediatrics, University of Copenhagen, Hvidovre Hospital, Denmark [K.F.M.]
\end{abstract}

\begin{abstract}
Bone $\gamma$-carboxyglutamic acid protein [BGP (osteocalcin)] is a protein synthesized by osteoblasts and incorporated in the bone matrix. Serum BGP is a sensitive marker of bone formation, and it parallels the growth velocity curve during childhood and adolescence. Serum BGP was measured at the age of 2,6 , and 9 mo in a cohort study of nutrition and growth in 91 healthy infants. At 2 mo, the mean BGP value $( \pm$ SD) was $275 \pm 87 \mathrm{ng} / \mathrm{mL}$ in infants exclusively breast-fed, and $80 \pm 44 \mathrm{ng} / \mathrm{mL}$ in formula-fed infants. At 6 mo, the values were $142 \pm 58 \mathrm{ng} /$ $\mathrm{mL}$ and $55 \pm 30 \mathrm{ng} / \mathrm{mL}$, and at $9 \mathrm{mo} 75 \pm 39 \mathrm{ng} / \mathrm{mL}$ and $45 \pm 19 \mathrm{ng} / \mathrm{mL}$ in partially breast-fed and formula-fed infants, respectively. The differences were significant $(p<$ $0.001)$ at all three ages. At 2 and 9 mo, breast-milk intake was measured by test-weighing. Serum BGP was positively correlated to breast milk intake (mL/ $\mathrm{kg}$ body wt) at 2 mo $(r=0.59, p<0.001)$ and $9 \mathrm{mo}(r=0.41, p=0.06)$. When breast-feeding was stopped, the high BGP concentrations were not sustained. There were no significant differences in linear growth velocity between breast-fed and formulafed infants and no correlation between BGP values and linear growth velocity. We speculate that either a factor in human milk or the level of minerals in human milk causes the high BGP values. Moreover, if the higher values are associated with increased osteoblast activity, then the remodeling or the mineralization of bone might be different in infants not being breast-fed. (Pediatr Res 31: 401-405, 1992)
\end{abstract}

\section{Abbreviations}

BGP, bone $\gamma$-carboxyglutamic acid protein (osteocalcin)

BGP is a 49-residue protein that contains three residues of the vitamin $\mathrm{K}$-dependent $\mathrm{Ca}^{++}$binding amino acid, $\gamma$-carboxyglutamic acid $(1,2)$. BGP is known to be synthesized only by the bone-forming cells, the osteoblasts, and in small amounts by the odontoblasts $(3,4)$. Although the majority of this protein accu-

Received October 4, 1990; accepted October 24, 1991

Correspondence and reprint requests: Kim Fleischer Michaelsen, Research Department of Human Nutrition, The Royal Veterinary and Agricultural University, Rolighedsvej 25, DK-1958 Frederiksberg, Denmark

Supported by a grant from Otto Mønsteds Fond and from the Danish Medical Research Council (12-5957, 12-7735), the Danish Agricultural and Veterinary Research Council (13-4048), the Danish Technical Research Council (16-4338 H), and the Danish Natural Research Council (11-7011). mulates in bone, nanomolar concentrations circulate in blood, where it can be measured by RIA $(5,6)$. The precise physiologic role of BGP in the skeleton is still unknown. However, the appearance of BGP in embryonic bone coincident with mineral deposition (7), its association with the hydroxyapatite component of the matrix (8), its chemoattractant property for cells capable of bone resorption (9), and its modulated synthesis by the calcitropic hormone $1,25-(\mathrm{OH})_{2} \mathrm{D}(3,10,11)$ suggest a role for BGP in the bone turnover.

The first year of life is the period with the highest linear growth velocity, and an extensive remodeling of all bones also takes place during that period (12). The amount of calcium and phosphorus retained during the first year of life is very high, and much interest has focused on the amount of bone minerals and the rate of absorption from different infant diets. Feeding makes a profound difference in the mineralization of bone in the preterm infant (13), and in term infants there is much interest in the influence of diet on bone minerals (13).

Several studies have demonstrated that serum BGP is a sensitive marker of bone formation $(14,15)$ and that it parallels the growth velocity curve in children and adolescents aged 2-19 y (16-18). One preliminary study of non-age-matched infants suggested that serum BGP concentrations were higher in breastfed infants (19).

The aim of the present study was to relate serum BGP concentrations in age-matched infants to the type of feeding and to linear growth velocity.

\section{MATERIALS AND METHODS}

The present study was part of the Copenhagen Cohort Study of Infant Nutrition and Growth, which is a prospective cohort study of infants born at Hvidovre Hospital, with the infants being followed from birth to the age of $12 \mathrm{mo}$. Singleton infants with a gestational age between 37 and $42 \mathrm{wk}$, a birth weight between the 10th and 90th percentiles for gestational age (20), and no severe disease or malformations who were born of Danish parents were eligible. The mothers were not influenced in their choice of feeding.

One hundred thirty-nine infants were selected at random for the study group and 112 for the control group from all the deliveries at Hvidovre Hospital from October 1987 to February 1988. The control group, which was not contacted before the infant was 9 mo old, was included in the study to check whether the close observation with food registrations, test weighings, anthropometry, and blood samples was influencing the feeding pattern of the infants in the study group. After parental information and consent, 91 infants entered the study group and 59 
infants entered the control group. Of the 91 infants who entered the study group, 84 completed the study up to the age of 12 mo. A detailed comparison of the study group and the control group will be published elsewhere. There were no significant differences between duration of breast-feeding in the two groups. The study was approved by the local ethics committee.

Anthropometry. Weight, knee-heel length using an infant knemometer (21), and crown-heel length using a measuring board were recorded. Growth velocity was calculated as the difference between two measurements divided by the number of days between the two measurements. The infant knemometer measures knee-heel length, and thereby growth velocity, with high precision in preterm and mature infants. The standard error in measuring knee-heel growth velocity (expressed as $\mathrm{mm} / \mathrm{d}$ ) over a 2 -mo period is approximately $0.02 \mathrm{~mm} / \mathrm{d}$, corresponding to a coefficient of variation of $7 \%$ when measuring infants from 1-3 mo (21). Ninety-nine percent of all measurements were done by the same observer (K.F.M.). The following examinations were used in the present study: $1,3,6,9$, and 12 mo.

Breast-feeding. Exclusive breast-feeding allowed supplements of water and up to two meals with formula or solids per week. Infants were classified as partially breast-fed as long as they were fed from the breast at least once daily. Infants were classified as formula-fed if they were not taking any breast milk, although some infants at the age of 6 and 9 mo were eating a mixed diet with cow's milk and no formula. All mothers intended to breastfeed. However, the number of infants weaned completely increased gradually throughout the study period from a few weeks after delivery. Twenty, 45 , and $66 \%$ of the infants were weaned completely at the age of 2,6 , and 9 mo, respectively. None of the infants were exclusively breast-fed for more than 6 mo. Infants still being partially breast-fed at the age of 9 mo were receiving an average of $318 \mathrm{~mL}$ (SD $201 \mathrm{~mL}$ ) of breast milk per $24 \mathrm{~h}$.

Human milk intake. Human milk intake was determined by test weighing the infants in their homes at the age of 2 mo (during $48 \mathrm{~h}$ ) and $9 \mathrm{mo}$ (during $5 \mathrm{~d}$ ). The infants were weighed on Sartorius (Westbury, NY) IP 65 electronic balances programmed to perform 40 weighings over a 10 -s period and to show the mean on a digital display.

Food records. Records of food intake were made by the parents when the infants were 2 mo (during $48 \mathrm{~h}$, weighing), 6 mo (during $24 \mathrm{~h}$, household measures), and 9 mo (during $5 \mathrm{~d}$, weighing) of age. Breast-feeding status was recorded monthly. Total calcium and phosphorus intake from all foods, including human milk, was calculated using the Dankost computer program, developed by the Danish National Food Agency. A calcium and phosphorus content in human milk of $235 \mathrm{mg} / \mathrm{L}$ ( 5.88 $\mathrm{mmol} / \mathrm{L})$ and $142 \mathrm{mg} / \mathrm{L}(4.54 \mathrm{mmol} / \mathrm{L})$, respectively, was assumed (22).

In $30(13 \%)$ cases where a serum BGP result was available, the food registration (food record and/or test weighing) was not performed or was regarded incomplete and excluded.

Venous blood samples. At 2, 6, and 9 mo, 86, 79, and 125 infants were available for blood tests. The remaining infants refused blood sampling or were absent. The mean ages at the day of the blood tests were: 2 mo $(61 \pm 3 \mathrm{~d}), 6$ mo $(185 \pm 8 \mathrm{~d})$, and 9 mo $(276 \pm 8 \mathrm{~d})$. For ethical reasons, venous puncture was only attempted once, and it was successful in 83,73 , and $77 \%$ of the infants at the age of 2,6 , and 9 mo, respectively. Serum was stored at $-20^{\circ} \mathrm{C}$ until analyzed.

Serum BGP was determined by RIA (23). The antiserum used was raised in rabbits immunized with purified intact calf BGP, and homogenous calf BGP was used for standard and tracer. The standards were analyzed in duplicate, and for each serum sample duplicate samples of two or more different dilutions were analyzed. The sensitivity of the assay was $0.8 \mathrm{ng} / \mathrm{mL}$, and the intraassay and interassay coefficients of variation were $<7 \%$ and $<12 \%$, respectively.

Serum calcium, phosphorus, and alkaline phosphatase were measured on an SMAC II autoanalyzer (Technicon Instruments Corp., Tarrytown, NY). The amount of blood was sufficient only for the analysis of BGP and not for the other tests in 13, five, and 11 infants at 2, 6, and 9 mo, respectively. Three of the alkaline phosphatase values were above 4000 units/L and were excluded from the analysis. They were assumed to be caused by acute infections, although this was not verified.

In the control group anthropometry, test weighing, food records, and blood samples were performed at the age of 9 mo only, and this group was therefore not included in the calculations of growth velocity.

All infants received vitamin $\mathrm{K}(1 \mathrm{mg})$ intramuscularly on the day of birth and a daily supplement of vitamin A (1200 IU), vitamin C (50 mg), and vitamin D (600 IU) from the age of 2 wk. At the age of $2 \mathrm{mo}$, the infants were receiving only standard formulas or human milk. The formulas had the following declared content: protein $15-17 \mathrm{~g} / \mathrm{L}$, energy $67 \mathrm{kcal} / \mathrm{mL}$, calcium $440 \mathrm{mg} / \mathrm{L}(11 \mathrm{mmol} / \mathrm{L})$, phosphorus $310 \mathrm{mg} / \mathrm{L}(9.9 \mathrm{mmol} / \mathrm{L})$, vitamin D 6-13 $\mu \mathrm{g} / \mathrm{L}$, and vitamin $\mathrm{K} 55 \mu \mathrm{g} / \mathrm{L}$ (vitamin $\mathrm{K}$ was only declared in one brand). One infant received an unmodified formula with a higher content of protein and minerals. No infant was exclusively breast-fed beyond the age of $6 \mathrm{mo}$.

Statistical methods. Sample means were compared by oneway analysis of variance. Pearson's product-moment correlation coefficient and regression analysis were used. All calculated $p$ values are two-tailed, and a $p$ value of less than 0.05 was considered to indicate statistical significance.

\section{RESULTS}

Serum BGP values were significantly higher in infants receiving breast milk at 2,6 , and 9 mo (Table 1). The values were highest at $2 \mathrm{mo}$, with decreasing values at 6 and $9 \mathrm{mo}$. No sex difference was observed in any of the groups. In 2-mo-old infants, there was a strong positive correlation $(B G P=31+1.7 \times \mathrm{mL}$ milk/kg; $r=0.59, n=54, p<0.001$ ) between serum BGP and the intake of breast milk corrected for body weight when infants exclusively breast-fed and infants partially breast-fed were both included in the regression (Fig. 1). However, there was also a significant positive correlation when only those exclusively breast-fed were included in the regression $(\mathrm{BGP}=111+1.2 \times$ $\mathrm{mL}$ milk $/ \mathrm{kg} ; r=0.30, n=45, p=0.04$ ). At the age of $9 \mathrm{mo}$, there was also a positive trend, almost reaching significance (BGP $=54+0.7 \times \mathrm{mL}$ milk $/ \mathrm{kg} ; r=0.41, n=19, p=0.06)$. The serum BGP values at the age of 9 mo were almost identical in the study group and the control group (Table 1), and in the following analysis these two groups have been combined.

To examine whether the effect of human milk influences the level of serum BGP after the infant is weaned completely, we have done the following analysis: The BGP values in infants who were no longer being breast-fed at 6 mo were compared according to breast-feeding status at the age of $2 \mathrm{mo}$, which was the time of the previous blood sample (Fig. 2). There were no significant differences in BGP values at the age of $6 \mathrm{mo}$, despite large differences in serum BGP values at 2 mo. Furthermore, serum BGP concentrations in formula-fed infants at the age of $6 \mathrm{mo}$ were compared according to breast-feeding status at the age of 4 mo, and no significant differences in BGP levels were found. The mean concentration $( \pm \mathrm{SD})$ was $55 \pm 27 \mathrm{ng} / \mathrm{mL}(n=9)$ in the infants being breast-fed at the age of 4 mo and $58 \pm 33 \mathrm{ng} /$ $\mathrm{mL}(n=15)$ in formula-fed infants.

Linear growth velocity during three periods was compared between breast-fed and formula-fed infants (Table 2). The three periods were chosen to correspond with the three ages for blood tests. No significant differences between breast-fed and formulafed infants were found. Relations between BGP values at 2, 6 , and 9 mo and linear growth velocity (crown-heel and knee-heel length) during the same three periods were examined, but no significant correlations were found.

Serum phosphorus was negatively correlated with BGP values 
Table 1. Serum BGP concentrations $(n g / m L)$ in infants according to breast-feeding status and age*

\begin{tabular}{lcccc}
\hline & $\begin{array}{c}\text { Exclusively } \\
\text { breast-fed }\end{array}$ & $\begin{array}{c}\text { Partially } \\
\text { breast-fed }\end{array}$ & Formula-fed & ANOVA $\dagger$ \\
\hline Study group & & & & \\
2 mo & $275 \pm 87(48)$ & $175 \pm 99(9)$ & $80 \pm 44(14)$ & $p<0.001$ \\
6 mo & & $142 \pm 58(32)$ & $55 \pm 30(26)$ & $p<0.001$ \\
9 mo & & $78 \pm 37(22)$ & $47 \pm 21(35)$ & $p<0.001$ \\
Control group $(9 \mathrm{mo})$ & $74 \pm 46(10)$ & $43 \pm 16(29)$ & $p<0.01$ \\
\hline
\end{tabular}

* Values are mean $\pm \mathrm{SD}(n)$.

$\uparrow$ ANOVA, one-way analysis of variance.

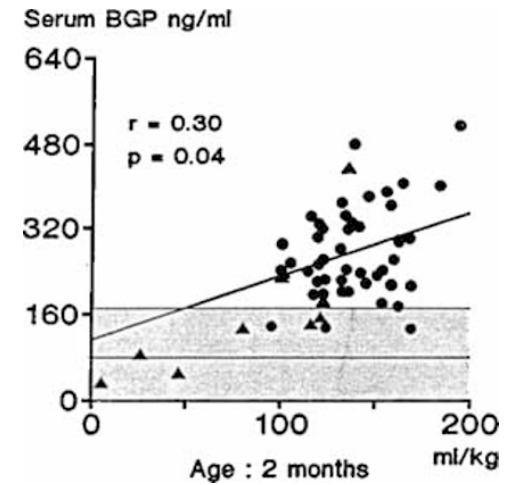

Fig. 1. Serum BGP according to intake of breast milk at the age of 2 mo. Shaded area represents mean \pm 2 SD of BGP values in formula-fed infants. The regression shown is based only on infants exclusively breast fed. If infants partially breast-fed are included, $r=0.59(p<0.001)$. exclusively breast-fed; $\boldsymbol{\Lambda}$, partially breast-fed.

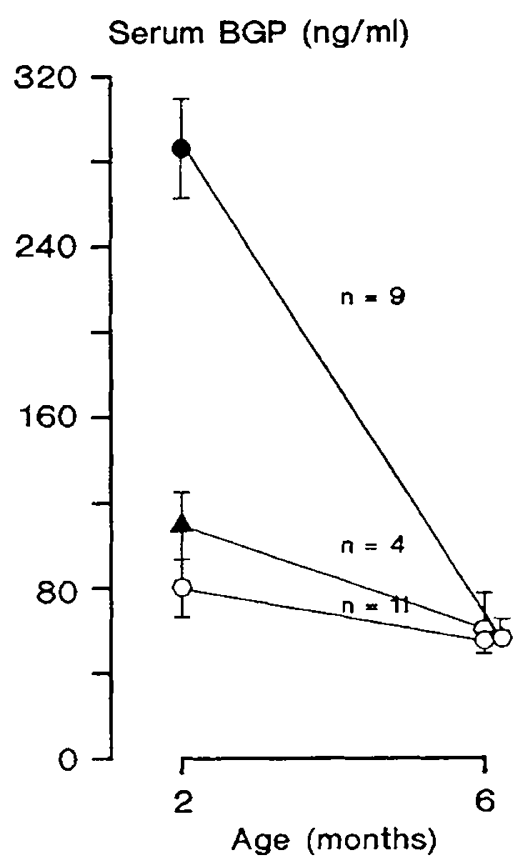

Fig. 2. Serum BGP in formula-fed infants at $6 \mathrm{mo}$, grouped according to breast-feeding status at the previous blood test $(2 \mathrm{mo})$. Only infants in whom it was possible to obtain a blood sample at both 2 and 6 mo have been included. $\bullet$, exclusively breast-fed; $\boldsymbol{\Lambda}$, partially breast-fed; and $\bigcirc$, not breast-fed.

at 2 and 6 mo $(r=-0.43, n=58, p<0.001$ and $r=-0.39, n$ $=53, p<0.01$, respectively), but not at $9 \mathrm{mo}(r=-0.15, n=$ 85 ). However, serum phosphorus could not explain a significant part of the variation in BGP at the age of 2 or 6 mo when it was entered in a multiple regression together with the amount of breast milk, expressed either as $\mathrm{mL} / 24 \mathrm{~h}(2 \mathrm{mo})$ or number of meals/24 h (6 mo). Serum calcium and serum alkaline phospha- tase concentrations were not significantly related to BGP concentrations.

The estimated daily intake of calcium and phosphorus is shown in Table 3. Calcium and phosphorus intake was strongly $(p<0.001)$ related to breast-feeding status at both 2 and 9 mo. To investigate the relative influence of human milk and mineral intake on the serum BGP level, we related human milk intake $(\mathrm{mL} / \mathrm{kg}$, volume $=0$ in formula-fed infants) and calcium and phosphorus intake $(\mathrm{mg} / \mathrm{kg})$ to serum BGP by multiple regression analysis. At $2 \mathrm{mo}$, only human milk intake was significantly $(p<0.0001)$ related to serum $\mathrm{BGP}\left(R^{2}=53 \%, n=68\right)$. At 9 mo, both human milk intake $(p=0.0001)$ and calcium intake ( $p=0.04$, negative regression coefficient) were significant $(n=$ 75 ). At this age, human milk intake alone, could explain $37 \%$ of the variation in BGP, and when calcium was also included in the regression $40 \%$ could be explained.

\section{DISCUSSION}

The major finding of this study was that breast-fed infants had significantly higher serum BGP values than formula-fed infants. The difference was most pronounced at the age of 2 mo when there was a 3 -fold difference in BGP values. We believe that the high values are caused by the intake of human milk, inasmuch as the level of serum BGP was positively correlated to the amount of breast-milk ingested and the effect of breast-feeding on BGP levels was not sustained when breast-feeding was stopped.

The RIA used for measuring serum BGP is sensitive, precise, and comparable with other BGP assays (24). All infants in this study were born at term and were growing at a normal rate. Breast-feeding is the physiologic way of feeding an infant, and the high concentration of serum BGP in breast-fed infants must be regarded as a normal physiologic response that is not elicited in formula-fed infants. The same pattern is seen in rats, in which serum BGP concentrations are very high during suckling $(\sim 500$ $\mathrm{ng} / \mathrm{mL}$ ); after weaning, the concentration drops rapidly (to $\sim 250$ $\mathrm{ng} / \mathrm{mL})(25,26)$.

It is unlikely that the measured BGP in the breast-fed infants originates from the mother. If so, it must be concentrated by the mammary gland, inasmuch as serum BGP in lactating women is $9.5 \mathrm{ng} / \mathrm{mL}(27)$ or approximately $1 / 25$ of the level in breast-fed infants at the age of 2 mo. BGP would also have to be absorbed intact through the gastrointestinal tract in large amounts.

Vitamin $\mathrm{K}$ status affects BGP synthesis, and vitamin $\mathrm{K}$ is a prerequisite for the synthesis of $\gamma$-carboxylated residues (8). If an increased amount of non- $\gamma$-carboxylated BGP is produced in breast-fed infants because of considerable vitamin K deficiency, then less of the protein would bind to bone and a larger proportion would be found in the circulation. Current RIA for serum BGP do not differentiate between $\gamma$-carboxylated and non- $\gamma$ carboxylated BGP (3). Hemorrhagic disease of the newborn is more prevalent in breast-fed infants (28), suggesting that vitamin $\mathrm{K}$ deficiency is more prevalent in breast-fed infants. Plasma BGP has been reported to be significantly lower in 1- to 3-mo-old infants who were given oral vitamin $\mathrm{K}_{2}$ at birth and on the 7 th $\mathrm{d}$ than in untreated infants. However, the children were not stratified according to type of feeding, and at 3 mo of age the 
Table 2. Linear growth velocity during three age intervals corresponding to age for blood tests according to breast-feeding status at time of blood sampling*

\begin{tabular}{|c|c|c|c|c|}
\hline & $\begin{array}{c}\text { Exclusively } \\
\text { breast-fed }\end{array}$ & $\begin{array}{c}\text { Partially } \\
\text { breast-fed }\end{array}$ & Formula-fed & ANOVA $\uparrow$ \\
\hline \multicolumn{5}{|l|}{ Velocity from 1 to $3 \mathrm{mo}$} \\
\hline Knee-heel mm/d & $0.30 \pm 0.07(48)$ & $0.27 \pm 0.06(9)$ & $0.32 \pm 0.06(14)$ & NS \\
\hline Crown-heel mm/d & $1.00 \pm 0.14(45)$ & $0.99 \pm 0.17(9)$ & $1.04 \pm 0.21(14)$ & NS \\
\hline \multicolumn{5}{|c|}{ Velocity from 3 to $9 \mathrm{mo}$} \\
\hline Knee-heel mm/d & & $0.18 \pm 0.03(30)$ & $0.19 \pm 0.03(23)$ & NS \\
\hline Crown heel mm/d & & $0.56 \pm 0.08(30)$ & $0.58 \pm 0.08(24)$ & NS \\
\hline \multicolumn{5}{|c|}{ Velocity from 6 to $12 \mathrm{mo}$} \\
\hline Knee-heel mm/d & & $0.15 \pm 0.03(21)$ & $0.15 \pm 0.03(34)$ & NS \\
\hline Crown-heel mm/d & & $0.43 \pm 0.06(21)$ & $0.41 \pm 0.06(35)$ & NS \\
\hline
\end{tabular}

* Values are mean $\pm \mathrm{SD}(n)$

$\dagger$ ANOVA, one-way analysis of variance.

Table 3. Calcium and phosphorus intake $(\mathrm{mg} / 24 \mathrm{~h})$ according to breast-feeding status and age*

\begin{tabular}{|c|c|c|c|c|}
\hline & $\begin{array}{c}\text { Exclusively } \\
\text { breast-fed }\end{array}$ & $\begin{array}{l}\text { Partially } \\
\text { breast-fed }\end{array}$ & Formula-fed & ANOVA $†$ \\
\hline \multicolumn{5}{|l|}{ Calcium } \\
\hline $2 \mathrm{mo}$ & $175 \pm 37(48)$ & $213 \pm 53(8)$ & $437 \pm 142(12)$ & $p<0.001$ \\
\hline $6 \mathrm{mo}$ & & NA $\ddagger$ & $574 \pm 214(24)$ & \\
\hline $9 \mathrm{mo}$ & & $401 \pm 147(22)$ & $666 \pm 207(53)$ & $p<0.001$ \\
\hline \multicolumn{5}{|c|}{ Phosphorus } \\
\hline $2 \mathrm{mo}$ & $106 \pm 23(48)$ & $136 \pm 40(8)$ & $298 \pm 87 \quad(12)$ & $p<0.001$ \\
\hline $6 \mathrm{mo}$ & & NA $\ddagger$ & $440 \pm 172(24)$ & \\
\hline $9 \mathrm{mo}$ & & $393 \pm 167(22)$ & $636 \pm 194(53)$ & $p<0.001$ \\
\hline
\end{tabular}

*Values are mean $\pm \mathrm{SD}(n)$. Calcium: $1 \mathrm{mg}=0.025 \mathrm{mmol}$. Phosphorus: $1 \mathrm{mg}=0.032 \mathrm{mmol}$.

$\dagger$ ANOVA, one-way analysis of variance.

$\ddagger$ Data on breast-milk intake not available.

difference in plasma BGP concentration had disappeared (29). We find it unlikely that the differences found in the present study are caused by vitamin $\mathrm{K}$ deficiency. First, an intramuscular injection of vitamin $\mathrm{K}$ was given to all infants at delivery. Second, there was still a significant difference in BGP concentration at the age of 9 mo when infants getting breast-milk were compared with formula-fed infants. At this age, the amount of breast-milk taken by the partially breast-fed infants is equivalent to only approximately $25 \%$ of the infants' energy intake. It is unlikely that this difference in diet could cause a marked difference in vitamin $\mathrm{K}$ status between the two groups.

The breast-fed infants in this study had a low intake of calcium and phosphorus compared with formula-fed infants, and in 9mo-old children calcium was inversly related to serum BGP level. 1,25-(OH $)_{2}$ D stimulates BGP synthesis (3), and the high BGP levels in breast-fed infants could be a result of increased serum $1,25-(\mathrm{OH})_{2} \mathrm{D}$ caused by a low dietary mineral intake. However, Lichtenstein et al. (19) could not find a correlation between the serum BGP and serum 1,25- $(\mathrm{OH})_{2} \mathrm{D}$ concentrations in infants and found no difference in the concentrations of serum $1,25-(\mathrm{OH})_{2} \mathrm{D}$ between breast-fed and formula-fed infants $(30)$.

The present data do not allow an explanation of the etiology of the large differences in serum BGP values. Likely explanations are either a factor in human milk, e.g. a hormone, growth factor, or vitamin that stimulates the osteoblasts to produce more BGP or increases the number of osteoblasts, or the differences in mineral intake between breast-fed infants and formula-fed infants. Despite a very large difference in serum BGP concentrations, we found no differences in linear growth velocity between breast-fed and formula-fed infants, which is in accordance with other studies $(31,32)$. Furthermore, there was no correlation between BGP values and linear growth velocity. If the high concentration of BGP in breast-fed infants reflects an increased osteoblast activity, the mineralization rate or the quality of the bone structure, and thereby the tensile strength, may be different in breast-fed infants than in formula-fed infants. We speculate that differences in diet during the first months of life may influence peak bone mass, which is an important determinant of the development of osteoporosis later in life.

\section{REFERENCES}

1. Hauschka PV, Lian JB, Gallop PM 1975 Direct identification of the calciumbinding amino acid, gamma-carboxyglutamate, in mineralized tissue. Proc Natl Acad Sci USA 72:3925-3929

2. Price PA, Otsuka AS, Poser JW, Kristaponis J, Raman N 1976 Characterization of a gamma-carboxyglutamic acid containing protein from bone. Proc Natl Acad Sci USA 73:1447-1451

3. Price PA, Baukol SA 1980 1,25-dihydroxyvitamin $D_{3}$ increases synthesis of the vitamin K-dependent bone protein by osteosarcoma cells. $\mathrm{J}$ Biol Chem 255:11660 -11663

4. Bronkers ALJJ, Gay S, DiMuzio MT, Butler WT 1985 Immunolocalization of gamma-carboxyglutamic acid containing proteins in developing molar tooth germs of the rat. Coll Relat Res 5:273-281

5. Price PA, Williamson MK, Lothringer JW 1981 Origin of the vitamin Kdependent bone protein found in plasma and its clearance by kidney and bone. J Biol Chem 256:12760-12766

6. Price PA, Nishimoto SK 1980 Radioimmunoassay for the vitamin K dependent protein of bone and its discovery in plasma. Proc Natl Acad Sci USA 77:2234-2238

7. Price PA, Lothringer JW, Baukol SA, Reddi AH 1981 Developmental appearance of the vitamin-K dependent protein of bone during calcification. J Biol Chem 256:3781-3784

8. Price PA 1985 Vitamin K-dependent formation of bone Gla protein (osteocalcin) and its function. Vitam Horm 42:65-108

9. Glowacki J, Lian JB 1987 Impaired recruitment and differentiation of osteoclast progenitors by osteocalcin-deplete bone implants. Cell Differ 122:49. 60

10. Lian J, Stewart C, Puchacz E, Mackowiak S, Shalhoub V, Collart D, Zambetti G, Stein G 1989 Structure of the rat osteocalcin gene and regulation of vitamin-D dependent expression. Proc Natl Acad Sci USA 86:1 143-1147

11. Beresford JN, Gallagher JA, Poser JW, Russell RGG 1984 Production of osteocalcin by human bone cells in vitro. Effects of $1,25(\mathrm{OH})_{2} \mathrm{D}_{3}$, $24,24(\mathrm{OH})_{2} \mathrm{D}_{3}$, parathyroid hormone, and glucocorticoids. Metab Bone Dis Relat Res 5:229-234

12. Royer P 1974 Growth and development of bony tissues. In: Davies JA, Dobbing $J$ (eds) Scientific Foundations of Paediatrics. William Heineman Medica Books, London, pp 376-399

13. Lucas A 1988 Symposium on assessment of bone mineralization in infants; summary and future directions. J Pediatr 113:248

14. Brown JP, Delmas PD, Malaval L, Edouard C, Chapuy MC, Meunier PJ 1984 Serum bone Gla-protein: a specific marker for bone formation in postmenopausal osteoporosis. Lancet 1:1091-1093 
15. Delmas PD, Malaval L, Arlot ME, Meunier PJ 1985 Serum bone Gla-protein compared to bone histomorphometry in endocrine diseases. Bone 6:339341

16. Cole DEC, Carpenter TO, Gundberg CM 1985 Serum osteocalcin concentrations in children with metabolic bone disease. J Pediatr 106:770-776

17. Delmas PD, Chatelain P, Malaval L, Bonne G 1986 Serum bone Gla-protein in growth hormone deficient children. J Bone Miner Res 1:333-338

18. Johansen JS, Giwercman A, Hartwell D, Nielsen CT, Price PA, Christiansen C, Skakkebæaek NE 1988 Serum bone Gla-protein as a marker of bone growth in children and adolescents: correlation with age, height, serum insulin-like growth factor I, and serum testosterone. J Clin Endocrinol Metab 67:273-278

19. Lichtenstein P, Gormley C, Poser J, Tsang RC, Specker B 1987 Serum osteocalcin concentrations in infancy: lower values in those fed cow milk formula versus breast feeding. J Pediatr 110:910 -911

20. Secher NJ, Hansen PK, Lenstrup C, Pedersen-Bjergaard L, Eriksen PS 1986 Birthweight for gestational age chart based on early ultrasound estimation of gestational age. Br J Obstet Gynaecol 93:128-134

21. Michaelsen KF, Skov L, Badsberg JH, Jørgensen M 1991 Short-term measurement of linear growth in preterm infants: validation of a hand-held knemometer. Pediatr Res 30:464-468

22. Report of a joint WHO/IAEA Collaborative Study 1989 Minor and trace elements in breast milk. World Health Organization, Geneva

23. Johansen JS, Mølholm Hansen JE, Christiansen C 1987 A radioimmunoassay for bone Gla protein (BGP) in human plasma. Acta Endocrinol (Copenh) $114: 410-416$
24. Delmas PD, Christiansen C, Mann KG, Price PA 1990 Bone Gla Protein (osteocalcin) assay standardization report. J Bone Miner Res 5:5-11

25. Price PA, Williamson MK 1981 Effects of warfarin on bone. Studies on the vitamin K-dependent protein of rat bone. J Biol Chem 256:12754-12759

26. Price PA, Williamson MK, Baukol SA 1981 The vitamin K-dependent bone protein and the biological response of bone to 1,25 dihydroxyvitamin $D_{3}$. In: Veis A (ed) The Chemistry and Biology of Mineralized Connective Tissues. Elsevier, Amsterdam, pp 327-335

27. Cole DE, Gundberg CM, Stirk LJ, Atkinson SA, Hanley DA, Ayer LA, Baldwin LS 1987 Changing osteocalcin concentrations during pregnancy and lactation: implications for maternal mineral metabolism. J Clin Endocrinol Metab 65:290-294

28. Kries RV, Shearer MJ, Gobel U 1988 Vitamin K in infancy. Eur J Pediatr 147:106-109

29. Yoshinaga M, Tsuji X, Tsutsumi C, Moriuchi S 1987 Possible role of bone gamma-carboxyglutamic acid-containing protein in the pathogenesis of vitamin $\mathrm{K}$ deficiency in early infancy. J Clin Biochem Nutr 2:217-231

30. Lichtenstein P, Specker BL, Tsang RC, Mimouni F, Gormley C 1986 Calciumregulating hormones and minerals from birth to 18 months of age: a crosssectional study. I. Effects of sex, race, age, season, and diet on vitamin D status. Pediatrics 77:883-890

31. Persson LA 1985 Infant feeding and growth: a longitudinal study in three Swedish communities. Ann Hum Biol 12:41-52

32. Whitehead RG, Paul AA 1984 Growth charts and the assessment of infant feeding practice in the western world and in developing countries. Early Hum Dev 9:187-207

\section{Announcement}

\section{The Second Congress of the European Society for the Study and Prevention of Infant Death}

The 2nd Congress of the European Society for the Study and Prevention of Infant Death (ESPID) will be held June 11-12, 1992 in Travemünde-Lübeck. There will also be a satellite meeting of SIDS Family Europe, the organization of parents from European countries. The first part of the satellite meeting will be held on June 10 and the second part on June 13 as a final joint session with ESPID. The joint sessions will make recommendations and guidelines concerning home care strategies including various aspects such as body position, bedding, and temperature control. The theme of the three plenary sessions of the ESPID Congress will be infant mortality in the three main regions of Europe: East, South, and Northwest. The scientific part of the congress will be organized by the five permanent workshops of the ESPID (Epidemiology, Clinical Problems, Physiology, Psychosocial Aspects, and Pathology). For further information, contact Prof. Dr. K. Bentele, Universitäts-Kinderklinik, Martinistrasse 52, 2000 Hamburg 20, Germany, phone: 040-468-2900, FAX: 040-4685107 or 4964. 